América sin nombre, n. 22 (2017) 93-98

DOI 10.14198/AMESN.2017.22.08

ISSN: 1577.3442 / eISSN: 1989-9831

Fecha de recepción: 21/02/2017

Fecha de aceptación: 23/03/2017
Puede citar este artículo como:

Noemí Perilli, Carmen. "Tomás Eloy Martínez. Entre la mosca y la mariposa". El cuento hispanoamericano del siglo XXI. Agustín Prado Alvarado (coordinador). América sin Nombre, 22 (2017): 93-98, DOI: 10.14198/AMESN.2017.22.08

Link para este artículo: http://dx.doi.org/10.14198/AMESN.2017.221.08

\title{
Tomás Eloy Martínez Entre la mosca y la mariposa

\author{
Tomás Eloy Martínez
} \\ Between fly and butterfly
}

\author{
Carmen Noemí Perilli* \\ Universidad Nacional de Tucumán (Argentina)
}

\section{Resumen}

La escritura de Tomás Eloy Martínez está atravesada por la necesidad de comprender el fenómeno del peronismo. «La novela de Perón aborda, por primera vez, la historia del mito del conductor desde la ficción. Lo hace en los primeros momentos de la vuelta a la democracia, cuando se comienza a volver sobre los pasos perdidos. Surge bajo la sombra de la denominada novela de dictadores. Santa Evita, en cambio, pertenece al tiempo del carnaval neoliberal de un peronismo liderado por Menem. En esa dirección apunta menos a buscar la verdad de la historia que a leer las redes tejidas por el deseo, alrededor del mito. Entre las dos media la distancia que separa la figura de la prosaica mosca de la etérea mariposa

Palabras claves: peronismo, biografía, archivo, verdad, mito

\begin{abstract}
Tomás Eloy Martínez' writing is marked by the need of understanding peronism. La novela de Perón addresses fictionally for the first time -in the frame of dictator's novels- the history of the leader's myth. This is done in the first years of democracy's recovery, when reflection on recent historical paths sets in.Santa Evita, by contrast, originates under Menem's peronist neoliberal carnival. It aims less at establishing historical truths than unravelling desires nets woven around the myth. In their differences, the novels recall the prosaic fly and the ethereal butterfly.
\end{abstract}

Keywords: peronism, biography, archive, true, myth

\footnotetext{
* Investigadora Principal CONICET y Profesora Titular «Literatura Latinoamericana» de la Universidad Nacional de Tucumán (Argentina). Directora de Telar. Revista del Instituto Interdisciplinario de Estudios Latinoamericanos. Entre sus libros se encuentran: Imágenes de la mujer en Carpentier y García Márquez. Las ratas en la Torre de Babel, Historiografía y ficción en la narrativa latinoamericana, Países de la memoria y el deseo: Jorge Luis Borges y Carlos Fuentes, Catálogo de ángeles mexicanos. Elena Poniatowska y Sombras de autor. La narrativa latinoamericana entre siglos. Entre sus compilaciones están, en col. Fabulas del género. Sexo y escritura en América Latina; Siluetas de papel. El autor como lector y Relatos Infieles.Tomás Eloy Martínez.
} 
La obra de Tomás Eloy Martínez abre un espacio de diversas texturas atravesado por obsesiones que se dicen como vida y muerte; pertenencia y exilio; cuerpo y letra. El mayor desafío del escritor reside en la renovación de la palabra para preservar la memoria y transmitir la densa trama de historia. Persigue los mitos, las sombras, las fábulas, las escenas que anidan en el imaginario nacional. La nación como "comunidad imaginada» se naturaliza; la historia y la leyenda le arman un pasado común que consolida hegemonías y la geografía le dibuja mapas de confusos límites. En esta escritura emerge una Argentina desgarrada en lucha consigo misma, amenazada por la insistencia de la incomprensión y la muerte.

Tomás Eloy Martínez no se permite visiones apocalípticas acerca de la literatura, apuesta al poder de la narración como posibilidad de conocimiento -narrar tiene la misma raíz que conocer. Incursiona en todos los lenguajes desde el cine al periodismo, siempre desde un espacio, la literatura. Convencido de la importancia del relato busca unir tradición y modernidad, apelando a géneros en los que no se aleje la información de la experiencia, a través del arte de contar historias. El hacedor de ficciones y el buscador de la verdad responden con una misma pasión: la lectura y la escritura. Una preocupación lo asedia: la relación entra el lenguaje y la realidad. En Santa Evita dice «Todo relato es, por definición, infiel. La realidad, como ya dije, no se puede contar ni repetir. Lo único que se puede hacer con la realidad es inventarla de nuevo». Combate contra y con la infidelidad de los relatos, sabe poner en escena los debates de la memoria y explorar los alcances de la invención.

El escritor tucumano recoge la propuesta de los proyectos liberales del siglo xIx. Lee la nación en los términos del relato de Domingo Faustino Sarmiento en el que la civilización lucha de modo permanente con la barbarie. El país es un organismo enfermo, que no logra superar el dorado pasado perdido para siempre. Sus ficciones exhiben una ontología negativa que ataca el concepto de linealidad del tiempo y denuncia la falacia de una identidad clausurada. La escritura re-significa modernidad y orden como formas de exterminio material y simbólico. Fundación y crimen se enhebran en mueca sombría en esos «relatos infieles» que quieren mostrar el otro lado de la trama.

La preocupación por la memoria y el archivo han atravesado la escritura latinoamericana del siglo xx. En la obra de Tomás Eloy Martínez se convierten en búsqueda obsesiva del archivo peronista sobre el que el escritor vuelve una y otra vez en ficciones y crónicas. Sus textos exhiben sucesivas mediaciones y escenifican vacíos de la memoria colectiva: «como los agujeros en los manuscritos, los textos flotantes cumplen la función de depósito, en el atesoramiento y acumulación de documentos» (González Echevarría 239). El autor sabe que no habría deseo de archivo sin la finitud radical, sin la posibilidad de olvido: «Lo real del archivo se convierte no sólo en huella sino también en planificación de las figuras de la realidad; y el archivo siempre mantiene una cantidad infinita de relaciones con lo real» (Farge 28).

Las narraciones "peronistas» abarcan dos grandes novelas: La novela de Perón y Santa Evita y varios libros de crónicas, testimonios y documentos: Las memorias del general reeditado como Las vidas del general; El sueño argentino; Réquiem por un pais perdido y Argentina y otras crónicas. Se puede incluir en ese corpus Lugar común la muerte, libro misceláneo y La pasión según Trelew, relato testimonial. El novelista se convierte en el testigo que interpela a Perón, como Sarmiento a Facundo Quiroga, el caudillo riojano. Como Quiroga Perón es la otra sombra terrible de la historia argentina de la segunda mitad del siglo $\mathrm{xx}$, que cifra el destino nacional. Una sombra que ha entablado un duelo a muerte entre Borges y Perón.

La historia del último medio siglo en la Argentina es, en el fondo, la historia del duelo a muerte entre Borges y Juan Perón. No sólo fue un duelo abierto, casi físico, entre el escritor que se negaba a nombrar a su enemigo y el dictador que desdeñaba a Borges llamándolo «ese pobre viejito ciego». Era también un duelo más hondo, más secreto, por prevalecer en la imaginación argentina. La frase favorita de Perón era un pleonasmo: «La única verdad es la realidad». Borges, que descreía de la realidad y de las verdades únicas, debió sentir aquella afirmación como un insulto» (Argentina y otras crónicas 77).

Explora el «sueño argentino», en el que la muerte se ha transformado en "lugar común», donde reinan impunidades y necrofilias. Un sueño en el doble sentido de utopía y de pesadilla, un sueño que acaba en réquiem por la patria. No le alcanzan mapas ni enciclopedias para explicar al país que lo ha enviado al exilio, que ha instalado un "purgatorio» donde desaparecen los cuerpos, en el que "la mano del amo» se ha transformado en la ley. La poética apela a un «barroco fúnebre» (Rosano) que impregna imaginarios literarios donde reinan la pérdida y la muerte, en una narrativa del fracaso. Me interesa comparar 
las novelas «peronistas» que ofrecen dos lecturas distintas y complementarias. La primera se articula alrededor de la biografía de Perón, en cambio la segunda es una tanatografía, donde el cadáver de Eva se convierte en la alegoría de la nación.

\section{Los ojos de la mosca}

La novela de Perón reúne la biografía (la novela sobre Perón) y la autobiografía (la novela escrita/ construida/ fabulada por Perón). Su aparición como folletín por entrega en la revista El Periodista de Buenos Aires (agosto de 1984 - junio de 1985) confundió al lector, ya que el texto se encontraba rodeado de fotos y gráficas, al modo de una investigación periodística. La aclaración decía: «El historiador o el biógrafo sabe que ningún hecho revela toda su verdad cuando se convierte en lenguaje... establecer la verdad en una masa de testimonios dispares y a menudo absolutamente contradictorios, es una tarea casi imposible» (25).

La obra se teje alrededor de una larga entrevista publicada como Las Memorias de Juan Perón $n^{1}$, transcriptas entre 1970 y 1974, en el semanario Panorama y remite a un breve relato "Perón sueña con la muerte» del libro Lugar común la muerte. Todos estos pre-textos actúan como causa de y se reescriben con una serie de transformaciones que legitiman el lugar ocupado por Tomás Eloy Martínez, autorizándolo a escenificar el duelo de versiones de la figura de Perón.

Al publicar las memorias de Juan Domingo Perón, yo había llevado mi fidelidad al «caso Perón» a varios extremos: no sólo había transcripto puntualmente su lenguaje y acordado con él el orden canónico en que serían presentados los hechos, sino que también había aceptado(luego de mostrarle documentos que contradecían sus versiones y de sugerir que los publicáramos) todas las distorsiones que Perón había querido imponer al relato de su vida, reservándome una sola advertencia: en esta historia yo era sólo el compilador, el mediador de la autobiografía (Las memorias del general 129).

En la novela la edición de Las Memorias, que componen una zona del libro, se atribuye al siniestro

1. De la investigación periodística surgió «Las primeras Memorias de Perón» publicadas en el diario La Opinión el 2 de julio de 1974. secretario José López Rega. Perón se presenta como el lector que comenta y actualiza el texto. Podríamos decir que el relato periodístico publicado por Tomás Eloy Martínez actúa como espacio de cruce de autorías: la de Perón, la de López Rega y la del mismo autor. No se puede dejar de advertir la intertextualidad con la novela Yo El Supremo de Augusto Roa Bastos. El que dicta (el dictador) observa cómo se lo convierte en personaje» (Perón).

Está corrigiendo sus Memorias. O, mejor dicho, va colocándose a sí mismo en las Memorias que ha escrito López: el General lleva meses viéndolo en el arduo trabajo de transcribir casetes y enredar documentos» (La novela de Perón 49).

Las Memorias dentro la novela fundan un sujeto que no vacila, cuyo discurso cree recordarlo todo y niega el olvido. El orden de la vida se funde con el orden de la escritura aunque, en el acto de la edición esta legalidad se deconstruya. En palabras de Griselda Zuffise trata de un «texto pantalla». La lectura de Perón deja caer «restos» que, al ser olvidados, contribuyen a la construcción del mito que subordina a los hechos históricos. "Alguien ha escrito por ahí que debo estudiar los documentos. Ajá. Aquí están los documentos, todos los que se me da la gana. Y si no están, López los inventa» (La novela de Perón 52).

Desde las primeras líneas el personaje del general es un denso pasado y un tembloroso futuro, como la estrella Beltegeuse que da nombre al avión que lo lleva a Buenos Aires. Antes de partir el hombre viejo revisa su biografía hasta 1945. Sus palabras son como las plumas que salen del claustro del cuerpo de Eva en el altillo de la casa: "Perón cerraba los ojos y se dejaba ir: iba soplando una historia tras otra, y era como si el cuarto se llenara de plumas» (La novela de Perón 55). El relato se teje desde la cercanía de la muerte, en el escritorio situado debajo del altillo donde se encuentra el cadáver de Eva. Una frase de Santa Evita revela la estrategia del autor

Pensé, siguiendo a Walter Benjamin, que cuando un ser histórico ha sido redimido se puede citar todo su pasado: tanto las apoteosis como lo secreto. Será tal vez por eso que en La novela de Perón sólo acerté a narrar lo más privado de Perón, no sus hazañas públicas: cuando trataba de abarcarlo por entero, el texto se me quebraba en los dedos (Santa Evita 64).

Perón personaje está fuera de la historia, su cuerpo está lleno de relatos diferentes, actúa como «una esponja» que se "desmigaja» hacia la muerte. Se ha transformado en una parodia de sí mismo, rodeado 
por una corte bufa de malevos, cantores de tango, brujos y amanuenses. A medida que se escribe (o lo escriben) va desvaneciéndose: "Las manos se le quedaban enredadas ente las toallas y los manteles, y cuando hasta la lencería fue embalada para el viaje, el cuerpo siguió aferrándose a las aureolas que los objetos dejaban por todas partes» (La novela de Perón $14)$; "sentía que un cuerpo ajeno procuraba desalojarlo de su cuerpo,y se aferraba a las barandas de la escalera para no perder el instinto de identidad" ( $L a$ novela de Perón 56).

Mientras tanto, en la convulsionada Buenos Aires que espera al líder, el periodista Zamora redacta las Contra-memorias que se publican como La vida entera de Perón-El hombre, El Lider. Documentos y relatos de cien testigos en la revista Horizonte (homónimo de Panorama). Sus «verdades» duplican el gesto de la novela y, como el autor de la novela, el personaje elige entretejer la vuelta del líder con su biografía temprana hasta 1945. Apela a los sobrevivientes que fueron testigos de la construcción de la fábula del militar (parientes, compañeros del ejército, amigos, enemigos) e incluye múltiples textos: el cuaderno de Mercedes, las cartas de la primera mujer, las notas del primo Julio y de su hermana, los testimonios de los compañeros, etc. Redacta una historia hecha de restos que se querían ocultos. En el hotel donde la milicia de López Rega prepara la tragedia, Zamora monta una patética «ópera del risorgymento» con los fantasmas del pasado. La masacre arrasa con los testigos; las letras quedan dispersas por el campo, desgarradas y se convierten en inservibles residuos como los cuerpos.

El autor resuelve la relación problemática entre el interior y el exterior del texto inscribiendo el nombre propio. Insiste en la necesidad de rescatar su voz, de apropiarse de la palabra, para contar «la verdad». Por una vez quiero ser el personaje principal de mi vida. No sé cómo. Quiero contar lo no escrito, limpiarme de lo no contado, desarmarme de la historia para poder armarme al fin con la verdad» (La novela de Perón 261).

No hay una sola verdad, sino múltiples versiones, y la realidad se presenta en forma confusa. La abuela Dominga le muestra al niño Juan Perón: «¿Qué ve una mosca, Juan? ¿Ve cuatro mil verdades o una verdad partida en cuatro mil pedazos?». La verdad de los ojos de la mosca es la verdad empírica que se multiplica en otras cuatro mil posibilidades, las cuatro mil verdades o las cuatro mil facetas de la verdad encontradas en el hedor de la basura. Los cuatro mil ojos multiplican las facetas de la realidad.
La biografía de Perón se teje entre la épica y la picaresca; contiene más silencios que hechos; más mentiras que verdades. El personaje Perón se ha forjado a sí mismo en su voluntad de perduración en la historia, es el producto más acabado del ejército, hijo del desierto patagónico y resultado de la corporación militar. Para ocultar sus debilidades ha enredado los documentos que contradicen la leyenda que decide proyectar. En la escena de la entrevista transcripta dentro del libro Tomás Eloy Martínez personaje cuenta:

Le oí decir exactamente lo que yo esperaba que dijera. Sentí que siempre adivinaba cómo lo veía el otro, que él se adelantaba a encarnar esa imagen. Había sido el conductor, el General, el Viejo, el dictador depuesto, el macho, el que te dije, el tirano prófugo, el cabecilla del GOU, el primer trabajador, el viudo de Eva Perón... Quién sabe qué otras cosas podría ser mañana. Tantos rostros le vi que me decepcioné. De repente, dejó de ser un mito. Finalmente me dije: él es nadie. Apenas es Perón (262).

La biografía gira alrededor del vacío y los agujeros de la memoria no impiden la lectura de la construcción del mito en el entrecruzamiento entre géneros diversos. La verdad de la historia tramada como tragedia está, en el recuerdo que funda el olvido pero también en el olvido que funda la memoria. Aunque siempre quedan residuos existe unidad del relato, el gesto biográfico. La muerte cierra el texto, la muerte del protagonista sobre el telón de fondo de la matanza de Ezeiza. Una inevitable violencia acompaña los tiempos finales de un Perón decrépito.

\section{Las alas de la mariposa}

Santa Evita aparece en un momento histórico muy diferente: los 90, la era menemista en la Argentina. La película de Alan Parker contribuye al auge de la figura de Eva, que se ha convertido en un ícono en la ópera. En el centro de la novela está la muerte, duplicando cuerpos y relatos pero sobre todo cadáveres. A medida que se consolida el relato mítico, la Evita histórica pierde carnadura y el simulacro se asienta en el vaciamiento que erige la Evita Eterna. Una de las primeros textos escritos por Tomás Eloy Martínez sobre la figura de Eva es la crónica «La tumba sin sosiego", donde narra un encuentro ocurrido en 1989. Un militar le entrega las claves del destino del cuerpo, que, como lo pronostica la madre 
«En vida, siempre había estado echándole tierra a su fuego, para no hacerle sombra al marido. Muerta, se iba a convertir en un incendio» (Santa Evita 47).

El biógrafo puede ser considerado una suerte de embalsamador, como el doctor Ara que postula «A un olvido hay que oponerle muchas memorias, a una historia real hay que cubrirla con historias falsas, Viva, su hija no tenía par, pero muerta, ¿qué importa? Muerta, puede ser infinita» (Santa Evita 55). Al mismo tiempo el novelista, con la infidelidad a la que le autoriza la ficción, compone una alegoría hecha de fragmentos y libera los relatos acerca de Eva y su cadáver. Las alas de la mariposa son un motivo constante y representan la dualidad de la protagonista. Una de esas alas mira hacia el pasado y narra la historia de vida de Eva y la otra hacia el presente y narra la del cadáver.

Pasaron algunas noches y soñé con Ella. Era una enorme mariposa suspendida en la eternidad de un cielo sin viento. Un ala negra se henchía hacia adelante sobre un desierto de catedrales y cementerios; la otra ala era amarilla y volaba hacia atrás, dejando caer escamas en las que fulguraban los pasajes de su vida en un orden inverso, el de la historia» (Santa Evita 65).

El cuerpo está lleno de palabras, imágenes y «cosas» que otros depositan en su interior, el duelo es interminable. Su travesía no afecta su poder, sino que lo enriquece en el misterio y la ausencia. "Esa mujer» se torna presencia oprobiosa, imperturbable fantasma ante el obligado nomadismo: «Poco a poco, Evita fue convirtiéndose en un relato que, antes de terminar, encendía otro. Dejó de ser lo que dijo y lo que hizo para ser lo que dicen que dijo y lo que dicen que hizo» (Santa Evita 21).

En la novela hay muchos enamorados: el embalsamador, el loco Arancibia, el coronel Mori Koenig, el mismo narrador. Si hay una propiedad de ese cuerpo vaciado y replicado es la de precipitar a todos, incluido el autor, en la desdicha. La muerta, inmutable, permanece fiel a sí misma y modifica a los demás y "cada quien construye el cuerpo que quiere, lee el cuerpo de Evita en las declinaciones de su mirada» (1995 203). El original se diferencia de las copias por el olor, como si insistiera en lo irreductible del aliento de la muerte. «Yo la hice» repiten todos hasta el cansancio, desde el peluquero hasta Juan Perón. Hay múltiples «hacedores», entre ellos están los escritores como Rodolfo Walsh, Copi, Néstor Perlongher. El compendio de historias-residuos recogidas por el narrador, adquiere la forma de melodrama. Los militares no pueden ignorar la proliferación de relatos acerca de Eva que ocupan el espacio de la nación, la desbordan. Las historias del pueblo van más allá del cuerpo y velas y flores acompañan el secreto viaje de la muerta. Aunque le den distintos nombres los disfraces no pueden atenuar el efecto letal del cadáver.

En las fichas la llamaba a veces Persona, a veces Difunta, a veces ED o EM, abreviando Eva Duarte y Esa Mujer. Cada vez era más Persona y menos Difunta: él lo sentía en su sangre, que más se enfermaba y cambiaba, y en otros como el mayor Arancibia y el teniente primero Fesquet, que ya no eran los mismos (Santa Evita 257).

En el texto observamos la incesancia de un movimiento inacabado. El texto se lee y, en ese gesto, canibaliza todo tipo de textos. El autor es un sujeto que habla con sombras, vive durante años buscando sigilosamente los pasos de un cadáver, se mueve en tiempos y espacios simultáneos y diferentes con absoluta libertad. El narrador nos dice: «Acumulé ríos de fichas y relatos que podrían llenar todos los espacios inexplicados de lo que, después, iba a ser mi novela. Por ahí los dejé, saliéndose de la historia, porque yo amo los espacios inexplicados» (Santa Evita 390). El espectáculo de la barbarie se convierte en una extraña forma de racionalidad. Eva, cuya vida puede verse como una sucesión de tarjetas postales, no representa, es. El relato elige una trama melodramática, sucesivas historias de amor con un cadáver.

La alegoría, señala Walter Benjamin, no es esa representación fiel y exacta del orden natural. Los objetos se tornan alegóricos al perder su significado inicial pero, precisamente al perderlo, ese objeto adquiere la capacidad de significar cualquier otra cosa distinta a la que significaba. La alegoría como fragmento-ruina nos ayuda a comprender una totalidad, que de repente coloca en conexión un fragmento con otro y nos permite así percibir un todo. «Evita era una enorme red que salía a cazar deseos como si la realidad fuera un campo de mariposas» (Santa Evita 75).

Las ficciones utópicas de mediados de siglo $\mathrm{xx}$ se basaron en conceptos inapelables de cambio histórico a los que la ficción finisecular problematiza; poniendo en duda su validez al interrogar construcciones y hacer evidente su retórica. Los textos incorporan la teoría como principio constructivo: teoría de la literatura y teoría de la historia. En este aspecto comparten las características de lametaficción historiográfica postmoderna occidental. Las tramas 
recogen rupturas y discontinuidades temporales y espaciales en el diseño histórico. Las novelas se alimentan de géneros no convencionales, reconociendo el carácter textual del acceso a lo real. Los relatos literarios quiebran la vocación de totalidad; prefieren bordear las ruinas e iluminarlas con reflexiones sobre la significación histórica y su vinculación con la letra.

La novela de Perón aborda, por primera vez, la historia del mito del conductor desde la ficción. Lo hace en los primeros momentos de la vuelta a la democracia, cuando se comienza a volver sobre los pasos perdidos. Surge bajo la sombra de la denominada novela de dictadores, el conjunto de novelas históricas que en el horizonte de los 80 construyeron una cartografía de las dictaduras latinoamericanas. Santa Evita, en cambio, pertenece al tiempo del carnaval neoliberal de un peronismo liderado por Menem. En esa dirección apunta menos a buscar la verdad de la historia que a leer las redes tejidas por el deseo, alrededor del mito. Entre las dos media la distancia que separa la figura de la prosaica mosca de la etérea mariposa. Si en la primera la escritura ronda el bios, en la segunda se centra en el cadáver, objeto que perdido sigue seduciendo, se vive en tiempo póstumo, se duda, a través del mismo funcionamiento de la máquina alegórica acerca da la derrota de la literatura. Las dos novelas pueden ser consideradas fallidas ficciones de archivo en tanto muestran no sólo la imposibilidad de armar un archivo, sino sus irremediables pérdidas.

\section{Bibliografía}

Agamben, Giorgio. Lo que queda de Auschwitz. El archivo y el testigo. Valencia: Pre-Textos, 2000.

Avelar, Idelber. Alegorías de la derrota: La ficción postdictatorialy el trabajo del duelo. Chile: Editorial Cuarto Propio, 2011.

Benjamin, Walter. Discursos interrumpidos I. Madrid: Taurus, 1982.

Benjamin, Walter. Para una crítica de la violencia y otros ensayos. Madrid: Taurus, 2001.

De Certeau, Michel. La escritura de la historia, México: Universidad Iberoamericana, 1993.
Debord, Guy. La sociedad del espectáculo. Buenos Aires: La marca, 1995.

FARGe, Arlette. La atracción del archivo, Valencia: Institución valenciana de estudios e investigación, 1991.

Franco, Jean. Decadencia y caida de la ciudad letrada. Barcelona: Debate, 2003.

González, Carina (comp.). Peronismo y Representación. Escritura e imágenes politicas del pueblo. Buenos Aires: Final Abierto, 2015.

González Echevarría, Roberto. Mito y Archivo. Una teoría de la narrativa latinoamericana. México: Fondo de Cultura Económica, 2000.

Intersimone, Luis. Melodrama Fundacional y Escatológico en el Peronismo. Tesis de Doctorado, Rutgers, The State Univ., of New Jersey, New Jersey, Enero: 2006.

Martínez, Tomas Eloy. «Las memorias de Juan Perón (1895-1945)». Semanario Panorama, Buenos Aires, Abril 14, 1970.

Martínez, Tomas Eloy. La novela de Perón. Buenos Aires: Sudamericana, Planeta, 1991.

Martínez, Tomas Eloy. Santa Evita. Buenos Aires: Planeta, 1995.

Martínez, Tomas Eloy. Las memorias del general, Buenos Aires: Planeta, 1996.

Martínez, Tomas Eloy. El sueño argentino; Buenos. Aires: Sudamericana, 1999.

Martínez, Tomas Eloy. Argentina y otras crónicas. Buenos Aires: Alfaguara, 2011.

Neyret, Juan Pablo. «Entre la sangre y el tiempo: Ética y estética del ensayo periodístico en Tomás Eloy Martínez», Revista Iberoamericana, LXXVIII: 240, (Julio-Septiembre 2012) 567-583.

Perilli, Carmen. Las ratas en la torre de Babel: La novela argentina entre 1982 y 1992. Buenos Aires: Letra Buena, 1994.

Perilli, Carmen (Comp.). Relatos infieles. Tomas Eloy Martinez. Tucumán: Editorial Universidad Nacional de Tucumán, 2016.

Rosano, Susana. "En definitiva en Argentina todos caemos en el barroco fúnebre. Reportaje a Tomás Eloy Martínez», Revista Iberoamericana, LXXII: 215-216, (Abril-Septiembre 2006) 657-662.

Zuffi, M. Griselda. Demasiado real. Los excesos de la historia en la escritura de Tomás Eloy Martínez (1973-1995). Buenos Aires: Corregidor, 2008. 